\title{
AN EXPLORATORY STUDY OF END USER COMPUTING STRATEGY: MANAGING FOR COMPLIANCE AND INNOVATION
}

\author{
Dr. Elaine Winston, Hofstra University, acserw@ hofstra.edu
}

\begin{abstract}
Currently, compliance and innovation are key organizational goals that are managed by end users. These goals, however, are often considered as separate managerial objectives that must compete for limited corporate resources. This study explores how mid-level managers use strategic IS to simultaneously achieve innovation and compliance goals. An overview of end user participation in the implementation process is presented. The results of a literature survey identify significant end user computing roles. Using qualitative case study data, three end user computing strategy types emerged for managers who rely on IS to achieve organizational goals. A surprising finding from this study is the success of the entrepreneur strategy that emphasizes creativity and self reliance. Finally, managerial implications and future areas of study are suggested.
\end{abstract}

Keywords: End User Computing, IS Implementation, Innovation, Compliance, Multiple Case Study

\section{INTRODUCTION}

Previous studies have documented the significant positive impact of end users as a major resource of Information Systems (IS) development in organizations [14]. End users, with an in-depth understanding of both business and customer, provide critical input during the IS implementation process. In response to periods of rapid technological change and increased government regulation end users embrace new business processes, job empowerment, and automation to help ensure a successful IS outcome $[3,11,13]$.

Other research suggests that the relationship between end-user participation and IS implementation success is still ill-defined and not well understood [5]. Currently, compliance and innovation are key organizational goals that are managed by end users $[1,4]$. These goals, however, are often considered as separate managerial objectives that must compete for limited corporate resources [6]. For example, standardization is vital to controlling business transactions and costs. The opposite applies to supporting innovation (i.e., flexibility is critical) [6].
This study explores how mid-level managers use strategic IS to simultaneously achieve innovation and compliance goals.

The presentation of this qualitative study begins with an overview of end user participation in the implementation process. The results of a literature survey identify end user computing approaches and roles. A description of the methodology and the findings from the data analysis follows. A critical theme regarding the manager's role and attitude towards IS-enabled innovation and compliance that emerged during the interview and data analysis process is then presented. Managerial implications of this study are discussed that can help both IT practitioners and end users when implementing a strategic IS. Finally, future research directions are offered.

\section{END USER PARTICIPATION}

IS implementation is the process to diffuse an information system within an organization. End user participation during a proposed six-stage process model is presented in Table 1 [17, 7]. IS implementation begins with scanning the environment for IT opportunities and adopting the appropriate IT. End users, who have knowledge of operations through hands- on experience, assist in accurately specifying business and customer information requirements $([15,21]$.

In the middle stages of the implementation an organization adapts the IS for the business and accepts the use of technology as part of regular work processes. This requires an understanding of how the IS supports organizational objectives [7, 12]. Details on how functions must be performed in order to be successful in larger defined business processes are generally the responsibility of end users. Therefore, end users may have valuable knowledge of the role that an IS has within the larger community.

The implementation may be a success technically. However, it may not achieve the maximum business benefit until the IS becomes routinized and institutionalized [7, 17]. Implementation success is determined by improvements in controlling and monitoring transactions and processes [8]. 
Additionally, the IS should improve the capacity of an organization to innovate [23]. This requires that end users develop the capability to assimilate and respond to new information [1].

Table 1. End-user Participation in IS Implementation Process

\begin{tabular}{|c|c|c|}
\hline \multicolumn{2}{|c|}{ Stage and Organizational Objectives } & Key end-user tasks \\
\hline Early & $\begin{array}{l}\text { 1. Initiate - Find IT solutions. } \\
\text { 2. Adopt - Gain organizational backing for } \\
\text { implementing IS. }\end{array}$ & - Identify business rules and requirements. \\
\hline Middle & $\begin{array}{l}\text { 3. Adapt - Develop, install, and maintain } \\
\text { IS. } \\
\text { 4. Accept - Organizational members } \\
\text { commit to IS use. }\end{array}$ & $\begin{array}{l}\text { - Design IS functionality. } \\
\text { - Execute organizational polices. } \\
\text { - Participate in change management. }\end{array}$ \\
\hline Late & $\begin{array}{l}\text { 5. Routinize - Encourage use of IS as a } \\
\text { normal activity. } \\
\text { 6. Institutionalize - Use IS in a } \\
\text { comprehensive and integrated manner. }\end{array}$ & $\begin{array}{l}\text { - Train in knowledge management. } \\
\text { - Contribute to innovation through increased } \\
\text { collaboration, communications and interactions. } \\
\text { - Manage compliance procedures and control } \\
\text { business transactions. }\end{array}$ \\
\hline
\end{tabular}

\section{END-USER COMPUTING ROLES}

The literature identifies end-user computing roles based on the attitudes and actions employees take in response to IS initiatives [19, 25, 26]. These roles include pioneers and champions or late adopters and laggards [3, 22]. Other related schemes indicate a responsibility in the IS implementation process, such as team member or liaison [9]. Various end user computing styles surface due to competitive and regulatory pressures that require a deep understanding on how to best use IS for transactions and interactions among diverse trading partners [23].

Pioneers strive to keep informed of new technologies through both internal and external exposure to new ideas $[2,10,22]$. These end users focus on individualism and often have strong opinions in regard to business and computer-related matters. Pioneers with their advanced knowledge of how an IS can be used innovatively will advocate their beliefs to other end users prior to IS diffusion. Once a new idea is championed, it is likely that others in the organization will adopt the innovation [3].

When an IS initiative, such as the implementation of a compliance program, hinders more favorable end user activities, then pioneers undertake a problem solving approach [10]. In many cases, pioneers will redefine an obstacle into a productive event by changing the negative aspects of the IS and adapting working procedures to better fit with the technology [2].
Other organizations may establish a team of end users and a culture that supports group effort to maximize the capabilities of an IS [2]. Networks, for example, permit end users to share knowledge that drives innovative behaviors [3, 19]. Further, team based activity that is focused on financial and accounting system issues may help ensure an organization-wide commitment to compliance.

End users that perform "liaison" duties coordinate the use of IS and business processes in their local areas [9]. They help to ensure that the IS becomes fully integrated in the work environment [25]. Additionally, liaisons establish social systems and cultures that embrace change and empower the end user $[22,24,26]$.

Some end users impede innovative ideas and opportunities by refusing to modify work processes, technology or themselves [2, 10]. They may, however, choose to collaborate with others. This allows end users to work at a small aspect of a larger problem. By coordinating IS tasks with colleagues, end users meet objectives and goals that they feel they could not attain by themselves [25].

\section{METHODOLOGY}

This multiple case study research used open-ended interviews to guide it, as presented in Appendix 1. Questions regarding end user involvement in IS implementation were based on the literature review. The open-ended questions permitted the participants to describe their involvement in a Customer 
Relationship Management (CRM) system implementation as well as their perceptions of how the IS supported innovation and compliance. These descriptions created a bank of rich and detailed data for analysis [20].

Ten business managers were interviewed between January and December, 2005. These managers all have had rigorous study in the management of information systems. All managers are located in a major metropolitan area and have significant work experience in highly competitive organizations such as McKinsey and Company, IBM, and Olympus America, Inc. Appendix 2 contains data about each participant in terms of type of business/industry, position in the business, type of IT implementation and role in IT implementation.

\section{FINDINGS}

This section discusses the main finding of this study, which is the emergence of three distinct end user computing profiles: Coordinator, Networker, and Entrepreneur. Table 2 indicates the data clusters and sample supporting statements for the three identified profiles. The manager's computing profile for each case is given in Appendix 2. To increase the validity of the profiles that were identified, more detailed descriptions and statements from the participant managers are offered.

Coordinator: I provide available time for end users to learn the functions of other positions in the organization. This enables the substitution of jobs and increases organizational flexibility and productivity. The CRM system increases control and regulation by prohibiting an end user from performing consecutive functions within one client evaluation (Case 1).

The system helped to open up the employees mind set with something new and exciting. Additionally, the IS improved collaboration among business owners, sales managers, and marketing and distribution personnel (Case 7).

Networker: We set up small creative think groups that discussed how to further identify IS-enabled changes and promote increased effectiveness and innovativeness (Case 8).

The organization established volunteer and temporary end user groups that promote efficiency and compliance, such as the "right the first time" group. Our web-enabled system provides internal and external users with access to a knowledge base that supports effective compliance with federally mandated regulations (Case 5).

Entrepreneur: I participate in on-line chats to learn about new methods and improve my expertise and knowledge. I identify new product design, packaging and promotional opportunities (Case 3).

I challenge the way things are currently done. The business promotes new ideas and actively seeks end user input in planning organizational and business process changes (Case 9).

Table 2. Manager's Computing Strategy

\begin{tabular}{|l|l|l|l|}
\hline Key Goals & \multicolumn{1}{|c|}{ Coordinator } & \multicolumn{1}{c|}{ Networker } & \multicolumn{1}{c|}{ Entrepreneur } \\
\hline Compliance & $\begin{array}{l}\text { Depend on secured system } \\
\text { rights to perform authorized } \\
\text { task in business process. } \\
\text { Rely on technology to } \\
\text { ensure rules and regulations } \\
\text { are followed and provide } \\
\text { documented support for } \\
\text { accounting audits. }\end{array}$ & $\begin{array}{l}\text { Create team of cross- } \\
\text { functional compliance } \\
\text { experts. } \\
\text { Maintain quality } \\
\text { control over data } \\
\text { shared within and } \\
\text { across organizations. }\end{array}$ & $\begin{array}{l}\text { Manage CRM/IS self-service features that } \\
\text { encourage compliance and accountability. } \\
\text { Identify and analyze outliers and } \\
\text { irregularities in documents/reports. }\end{array}$ \\
\hline Innovation & $\begin{array}{l}\text { Coordinate IS } \\
\text { implementation, functional } \\
\text { responsibilities and tasks, } \\
\text { and business process } \\
\text { changes. }\end{array}$ & $\begin{array}{l}\text { Actively participate } \\
\text { in cross functional } \\
\text { and inter- } \\
\text { organizational teams } \\
\text { and in on-line forums } \\
\text { to promote ideas and } \\
\text { share information. }\end{array}$ & $\begin{array}{l}\text { Provide key insights on new product } \\
\text { development by performing tasks across- } \\
\text { functional areas. } \\
\text { Apply high-level knowledge to customer } \\
\text { concerns, requests and expectations. } \\
\text { Search for creative ideas to add value to } \\
\text { products, services and processes. }\end{array}$ \\
\hline
\end{tabular}


The following suggestions may help end users improve their use of IS, such as CRM systems, to achieve innovative and compliance objectives.

- In some organizational contexts IS personnel may rely on end-users' creativity, self reliance and self discipline for compliance and innovation.

- Organizational innovation requires that end-users transfer their knowledge to information that may be shared across informal networks, both internally and externally.

- Formal collaborative teams may be used to uncover hidden pockets of organizational knowledge that will be critical to sustaining innovation and compliance initiatives.

\section{CONCLUSION}

The findings center on the emergence of three different end user computing strategies. These strategies helped managers using CRM systems achieve innovative and compliant directives, as evident in Table 2. The biggest surprise to surface, however, concerns the entrepreneur type of managers who were able to act creatively and use their independence to be self-reliant on compliance and regulatory issues. Table 3 displays a summary of the findings of this study.

Table 3. Summary of Findings

\begin{tabular}{|c|l|l|}
\hline $\begin{array}{c}\text { End } \\
\text { User/Manager } \\
\text { Strategy }\end{array}$ & \multicolumn{1}{|c|}{ Contributors of Compliance } & \multicolumn{1}{c|}{ Contributors of Innovation } \\
\hline Coordinator & $\begin{array}{l}\text { IS and coordination among various } \\
\text { business functions. }\end{array}$ & $\begin{array}{l}\text { Interdependence with other employees and } \\
\text { departments, Collaboration (mandatory). }\end{array}$ \\
\hline Networker & $\begin{array}{l}\text { Web-enabled IS, Informal Teams, } \\
\text { Trust and Openness. }\end{array}$ & $\begin{array}{l}\text { Collaboration (voluntary), Communities of } \\
\text { Knowledge, IS-enabled Communication. }\end{array}$ \\
\hline Entrepreneur & $\begin{array}{l}\text { Self discipline, Creativity, } \\
\text { Knowledge-based system. }\end{array}$ & Leadership, Creativity, Expertise and Knowledge. \\
\hline
\end{tabular}

This study suggests that planning an end user computing strategy during IS implementation may have a critical impact on the organization's ability to manage compliance and innovation. New technologies, such as internet and communication technology, impact management and the practice of end user/manager computing. There has been a decrease in research activity concerning end user computing models. Future research will need to readdress end user computing strategy in order to achieve the organizational benefits expected of costly IT initiatives such as compliance efforts.

\section{REFERENCES}

1. Abernethy, M. \& Bouwens, J. (2005). Determinants of Accounting Innovation Implementation, Abacus, 41(3), 217-240.

2. Beaudry, A. \& Pinsonneault, A. (2005). Understanding User Responses to Information Technology: A Coping Model of User Adaptation MIS Quarterly, 29(3), 493-524.
3. Brancheau, J.C. \& Wetherbe, J.C. (1990). The adoption of spreadsheet software: testing innovation diffusion theory in the context of enduser computing. Information Systems Research, l(2), 115-143.

4. Brown, J. \& Hagel III, J. (2005). From Push to Pull: The Next Frontier of Innovation, The Mckinsey Quarterly, (3), 82-91.

5. Butler, T. \& Fitzgerald, B. (2001). The Relationship Between User Participation and the Management of Change Surrounding the Development of Information Systems: A European Perspective. Journal of End User Computing, 13(1), $12-25$.

6. Cone, E, (2005). Can IT Deliver Inspiration and Perspiration? ClO Insight, 06/05/05.

7. Cooper, R.B. \& Zmud, R.W. (1990). Information Technology Implementation Research: A Technology Diffusion Approach, Management Science 36(2), 123 -139.

8. D'Agostino, D. (2005). A Rock and A Hard Place, CIO Insight (August). 
9. ElSawy, O. (1985). Implementation by Cultural Infusion: An Approach for Managing the Introduction of Information Technologies, MIS Quarterly, 9(2), 131-140.

10. Folkman, S. \& Moskowitz, J. (2002). Positive Affect and the Other Side of Coping, American Psychologist, 55(6), 647-654.

11. Hippel, E.V. (2001). Innovation by User Communities: Learning from Open-Source Software, Sloan Management Review, 82 - 86.

12. Iivari, J., \& Ervasti I. (1994). User Information Satisfaction: IS Implementability and effectiveness. Information and Management, 27(5), 205220.

13. Ives, B \& Olson, M. (1984). User Involvement and MIS Success: A Review of Research, Management Science, 30(5), 586-603.

14. Kettinger, W. \& Lee, C. (2002). Understanding The IS-User Divide in IT Innovation, Communications of the ACM. 45(2), 79 - 84.

15. Ko, C. \& Hurley, M. (1995). Managing EndUser Computing, Information Management \& Computer Security. 3(3). 3 - 6.

16. Kwok, S. H. \& Gao, S. (2005-2006). Attitude Towards Knowledge Sharing Behavior. Journal of Computer Information Systems, 46(2), 45-51.

17. Kwon, T. \& Zmud, R. (1987). Unifying the Fragmented Models of Information Systems Implementation. In R. J. Boland \& R.A. Hirchheim (eds.) Critical Issues in Information Systems Research, John Wiley \& Sons Ltd.
18. La Plante, A. (1991). The Ups and Downs of End-User Involvement, InfoWorld, 13(47), 45.

19. Larsen, T. \& Wetherbe, J. (1999). An exploratory field study of difference in information technology use between more and less innovative middle managers, Information and Management, (36), 93-108.

20. Marshall, C., \& Rossman, G. 1995 Designing Qualitative Research, 2nd Ed, Sage Publications.

21. McKeen, J. \& Guimaraes. (1997). Successful Strategies for User Participation in Systems Development, Journal of Management Information Systems, 14(2), 133 - 150.

22. Rogers, E. M. 1995. Diffusion of innovations. 4th ed. NY, NY: The Free Press.

23. Sifonis, J. (2001), Motivating staff for new strategies, Cisco Systems iQ magazine. http://www.cisco.com (visited March 11, 2006).

24. Winston, E. R. (2002). IS Consultants and the Change Agent Role, Computer Personnel, 20(4), 55-74.

25. Winston, E. \& Dologite, D. (2002). How does Attitude Impact IT Implementation: A Study of Small Business Owners, Journal of End User Computing, 14(2), 16-29.

26. Yuandong, Y., Wu, Z., \& Tung, L. (2005-2006). How Individual Differences Influence Technology Usage Behavior? Toward An Integrated Framework. Journal of Computer Information Systems, 46(2), 52-63. 
Appendix 1. Abbreviated Interview Guide

Interview Guide \#___ Manager Position___ Industry ___ Managerial functions
Organization

1. What is your position and involvement in the CRM system implementation and use?

2. Explain /Describe the Information System (include purpose of IS, how it was developed: either through the use of consultants or in-house IS, platform of system i.e., enterprise system, web-enabled, or stand-alone system, such as a spreadsheet program).

3. How do you (i.e., as an end user) assist in system development and implementation? (Probe: who are the endusers of the system).

4. Specifically, how does the CRM/IS support or enhance organizational innovation?(Probe: What system functions support innovation? What are your attitudes and beliefs concerning your ability to innovate using an IS, such as a CRM system).

5. Specifically, how does the CRM/ IS support regulatory issues? (Probe: Describe how compliance impacts your organization. Is your organization's CRM initiative related to Sarbanes Oxley? What are your attitudes and beliefs concerning your ability to manage compliance initiatives).

6. What goals are achieved through the CRM/IS system?

7. How are end users/stakeholders using the information system?

8. Is on-line training available for employees of the organization, clients, customers, etc.?

9. How do you/employees at your organization show/prove that they are innovative? (Probe: How do you see yourself as a change agent?).

Appendix 2. Participant Profiles

\begin{tabular}{|c|c|c|c|c|c|}
\hline $\begin{array}{l}\text { End user } \\
\text { /Manager }\end{array}$ & $\begin{array}{c}\text { End user } \\
\text { Computing } \\
\text { Strategy }\end{array}$ & Function & System & $\begin{array}{c}\text { Management } \\
\text { Position in } \\
\text { Implementation }\end{array}$ & Industry \\
\hline 1. Randy & Coordinator & IT support & $\begin{array}{l}\text { Medical Assistance } \\
\text { Tracking IS } \\
\text { (MATIS) }\end{array}$ & Application developer & $\begin{array}{l}\text { Social Services } \\
\text { (NYC) }\end{array}$ \\
\hline 2. Mark & Entrepreneur & $\begin{array}{l}\text { Product } \\
\text { Manager }\end{array}$ & $\begin{array}{l}\text { Product } \\
\text { Registration "Out } \\
\text { of Box Experience } \\
\text { Committee" }\end{array}$ & $\begin{array}{l}\text { "Out of Box } \\
\text { Experience } \\
\text { Committee" } \\
\text { Chairperson }\end{array}$ & $\begin{array}{l}\text { Consumer } \\
\text { Electronics }\end{array}$ \\
\hline 3. Chris & Entrepreneur & $\begin{array}{l}\text { Manufacturers } \\
\text { Representative }\end{array}$ & $\begin{array}{l}\text { Web- } \\
\text { enablement/Self } \\
\text { Service \& Sales } \\
\text { tracking }\end{array}$ & $\begin{array}{l}\text { Client end user of } \\
\text { CRM system: make } \\
\text { recommendations }\end{array}$ & $\begin{array}{l}\text { Industrial } \\
\text { Equipment. } \\
\text { Manufacturer }\end{array}$ \\
\hline 4. Nancy & Coordinator & $\begin{array}{l}\text { Branch } \\
\text { Manager }\end{array}$ & Enterprise & $\begin{array}{l}\text { Alliance Team: } \\
\text { Liaison to Branch } \\
\text { Employees }\end{array}$ & Banking \\
\hline 5. John & Networker & $\begin{array}{l}\text { IS personnel: } \\
\text { Shift Team } \\
\text { Leader (client } \\
\text { end user) }\end{array}$ & $\begin{array}{l}\text { Global Engineering } \\
\text { Management } \\
\text { System }\end{array}$ & $\begin{array}{l}\text { Client end user: make } \\
\text { recommendations, } \\
\text { Select group of } \\
\text { engineers - became } \\
\text { in-house trainers }\end{array}$ & Pharmaceuticals \\
\hline 6. Paul & Networker & IS Personnel & Enterprise System & Functional Lead & Telecommunications \\
\hline 7. Kathy & Coordinator & Accountant & Data Warehouse & End user & $\begin{array}{l}\text { Distribution of } \\
\text { Consumer Products }\end{array}$ \\
\hline 8. Carl & Networker & IS personnel & $\begin{array}{l}\text { Web-enabled/Self } \\
\text { Service }\end{array}$ & End user & Financial Services \\
\hline 9. Anna & Entrepreneur & IS Developer & SAP & IS developer & Consumer Pkgd Gds \\
\hline 10. Chris & Entrepreneur & CEO & $\begin{array}{l}\text { Web-enabled/Self } \\
\text { service system }\end{array}$ & End user & Communications \\
\hline
\end{tabular}

